\title{
Severe liver injury due to Epsom salt naturopathy
}

\author{
Cyriac Abby Philips, ${ }^{1}$ Rajaguru Paramaguru, ${ }^{2}$ Pushpa Mahadevan, ${ }^{3}$ Philip Augustine ${ }^{4}$
}

'Department of Hepatology and Transplant Medicine, PVS Memorial Hospital Ltd, Cochin, Kerala, India

${ }^{2}$ Department of Pathology, PVS Memorial Hospital Ltd, Cochin, Kerala, India

${ }^{3}$ Department of Pathology, Lakeshore Hospital and Research Centre Ltd, Cochin, Kerala, India

${ }^{4}$ Department of

Gastroenterology, PVS Memorial Hospital Ltd, Cochin, Kerala, India

\section{Correspondence to}

Dr Cyriac Abby Philips,

abbyphilips@gmail.com

Accepted 8 August 2017

CrossMark

\section{To cite: Philips CA,} Paramaguru R, Mahadevan $P$, et al. BMJ Case Rep Published Online First: [please include Day Month Year]. doi:10.1136/bcr-2017221718

\section{DESCRIPTION}

A 38-year-old non-alcoholic, non-diabetic man with gallstone disease was prescribed three tablespoons of Epsom salt (magnesium sulfate crystals) with lukewarm water for 15 days for 'stone dissolution' by a naturopathy practitioner. He developed loss of appetite and darkening of urine from the 12th day on treatment and jaundice from the second day after treatment completion. The patient denied fevers, skin rash, joint pains, myalgia, abdominal pain, abdominal distension and cholestatic symptoms. Examination revealed a deeply icteric patient oriented to time, place and person without organomegaly or stigmata of chronic liver disease. Blood investigations revealed platelet count 190 (normal $150-450 \times 10^{9} / \mathrm{L}$ ), total bilirubin $12.8(39.3 \mathrm{mmol} / \mathrm{L}$ ) (normal $0.3-1.0 \mathrm{mg}$ $\mathrm{dL}$ or $5.0-17.0 \mathrm{mmol} / \mathrm{L})$, direct bilirubin $6.9(21.7$ $\mathrm{mmol} / \mathrm{L})(0.0-0.2 \mathrm{mg} / \mathrm{dL}$ or $0.0-3.4 \mathrm{mmol} / \mathrm{L})$, aspartate aminotransferase $508(<37 \mathrm{U} / \mathrm{L})$, alanine aminotransferase $228(<41 \mathrm{U} / \mathrm{L}), \gamma$-glutamyltransferase 298
(5-61 U/L), alkaline phosphatase 178 (35-129U/L), albumin $4.2 \quad(3.5-5.0 \mathrm{~g} / \mathrm{dL})$ and international normalised ratio $1.1(0.9-1.2)$. $\mathrm{R}$ ratio was 3.84 and Roussel Uclaf Causality Assessment Method score was 8 (probable adverse drug reaction). Serum magnesium was $3.1(1.7-2.4 \mathrm{mg} / \mathrm{dL})$. Tests for viral hepatitis A, E, B, C, cytomegalovirus, Epstein-Barr and herpes simplex viruses and those for autoimmune hepatitis and IgG4 disease were unremarkable. There was no evidence of underlying sepsis and other organ failures. Contrast enhanced CT of upper abdomen revealed only hepatomegaly with mild periportal oedema. Percutaneous liver biopsy revealed submassive necrosis with dense portal-based fibrosis, mixed portal inflammation, extensive perivenular canalicular and hepatocellular cholestasis with macrovesicular steatosis and perisinusoidal fibrosis (suggestive of steatohepatitis) without evidence of granulomas, inclusion bodies or vascular changes suggestive of acute drug-induced liver injury (figure 1). Polarising

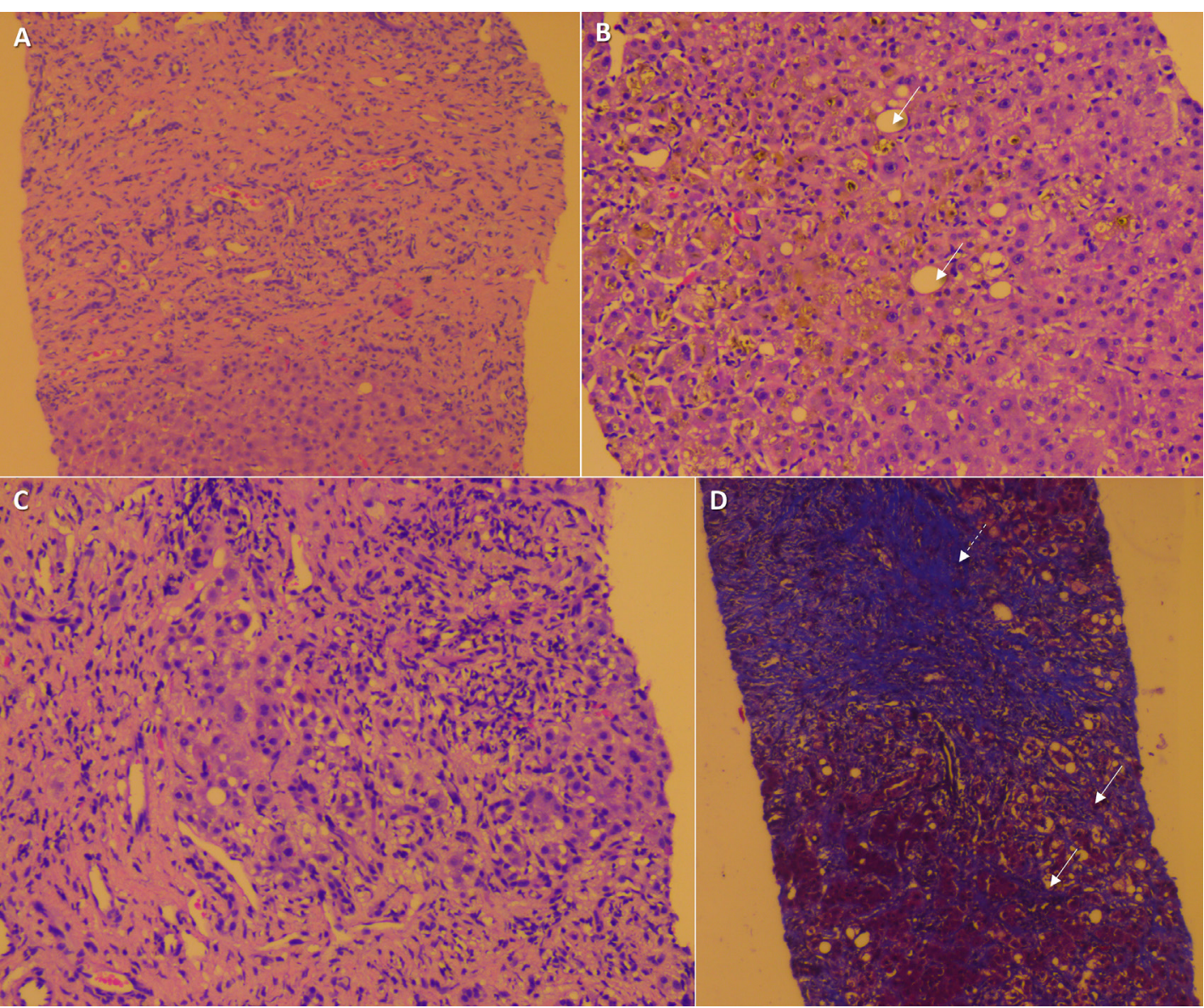

Figure 1 Liver histopathology showing (A) extensive submassive necrosis and collapse of liver parenchyma (H\&E stain, 10x); (B) perivenular hepatocellular and canalicular cholestasis with mild macrovesicular steatosis (arrows, H\&E stain, 20x); (C) portal-based mixed inflammatory cellular reaction (H\&E stain, 40x); (D) dense portal fibrosis (dashed arrow) and perisinusoidal fibrosis (arrows, Masson's trichrome stain, 20x). 
microscopy did not reveal crystalline deposits. Drug withdrawal and adequate hydration were instated and the patient had an uneventful recovery with normalisation of liver function tests after 38 days. Common adverse effects of Epsom salt overuse include diarrhoea, dyselectrolytaemia, renal injury and cardiac arrhythmias. ${ }^{12}$ Liu et al described the patterns of mineral-associated hepatic injury due to inhalational or intravenous exposure with pure silica, chromium-cobalt alloy and magnesium silicate (talc) in seven patients. ${ }^{3}$ They demonstrated that silica led to formation of sclerohyaline nodules within portal tracts and lobules in contrast to magnesium silicate injury that was associated with a predominant reactive fibrosis in portal and centrilobular areas. These patients were chronically exposed, in contrast to our patient who consumed Epsom salt in large quantities within a short period of time leading to predominantly necrotic and dense reactive fibrotic type of injury. Epsom salt-related severe liver injury and its histopathology have not been described in literature before. The Roussel Uclaf Causality Assessment Method (RUCAM) score was strongly suggestive of Epsom salt injury in our patient. We believe that underlying non-alcoholic steatohepatitis potentiated extensive liver injury in our patient, which resolved on stopping the offending agent.

Contributors CAP wrote the manuscript. RP and PM provided pertinent images and revised the manuscript. PA provided critical revisions and is the primary physician caring for the patient. All authors approved the final version of the manuscript.

\section{Learning points}

- Epsom salt intake could lead to severe injury in predisposed patients.

- Non-alcoholic fatty liver disease or steatohepatitis could act as a potential risk factor for development of magnesium sulfate liver injury.

- Oral magnesium salt-related liver injury has a predominant dense portal-based expansile reactive fibrosis and associated necrosis with mixed cellular inflammation.

Competing interests None declared.

Patient consent Obtained.

Provenance and peer review Not commissioned; externally peer reviewed.

(c) BMJ Publishing Group Ltd (unless otherwise stated in the text of the article) 2017. All rights reserved. No commercial use is permitted unless otherwise expressly granted.

\section{REFERENCES}

1 Nordt SP, Chen J, Clark RF. Severe hypermagnesemia after enteral administration of Epsom salts. Am J Health Syst Pharm 2011;68:1384-5.

2 Milne H, Dean P, Hughes M. Deliberate overdose with Epsom salts. BMJ Case Rep 2009;2009:bcr0720080591.

3 Liu YC, Tomashefski J, McMahon JT, et al. Mineral-associated hepatic injury: a report of seven cases with X-ray microanalysis. Hum Pathol 1991;22:1120-7.

Copyright 2017 BMJ Publishing Group. All rights reserved. For permission to reuse any of this content visit http://group.bmj.com/group/rights-licensing/permissions.

BMJ Case Report Fellows may re-use this article for personal use and teaching without any further permission.

Become a Fellow of BMJ Case Reports today and you can:

- Submit as many cases as you like

- Enjoy fast sympathetic peer review and rapid publication of accepted articles

- Access all the published articles

Re-use any of the published material for personal use and teaching without further permission

For information on Institutional Fellowships contact consortiasales@bmjgroup.com

Visit casereports.bmj.com for more articles like this and to become a Fellow 